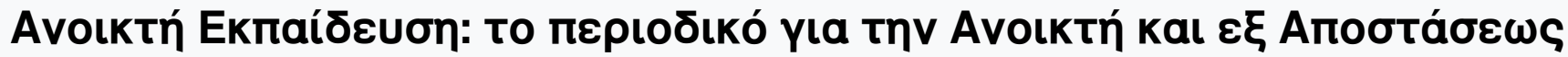

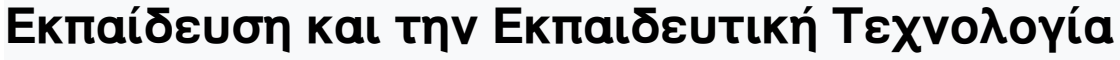

Tón. 7, Ap. 1 (2011)

Open Education - The Journal for Open and Distance Education and Educational Technology

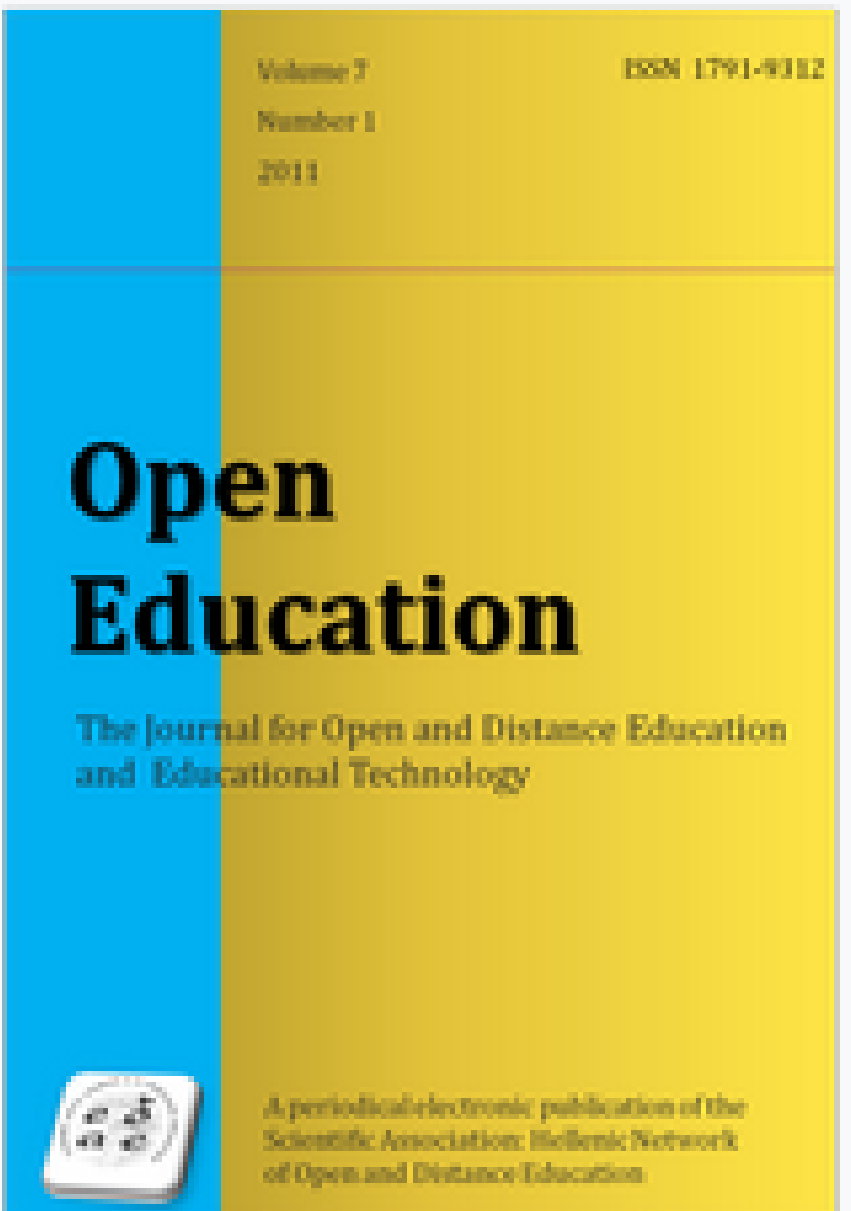

Digital Radio Broadcast: New technological resources to produce educational programs online

Marcelo Mendonça Teixeira, Bento Duarte Silva

doi: $10.12681 /$ jode. 9770

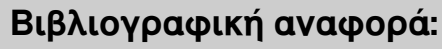




\title{
DIGITAL RADIO BROADCAST: NEW TECHNOLOGICAL RESOURCES TO PRODUCE EDUCATIONAL PROGRAMS ONLINE ${ }^{1}$
}

\author{
Teixeira, Marcelo Mendonça \\ Universidade do Minho, Portugal \\ Doctoral Student in Educational Technology \\ marcelo.uminho.pt@gmail.com \\ Silva, Bento Duarte \\ Universidade do Minho, Portugal \\ Associate Teacher Doctor \\ bento@iep.uminho.pt
}

\begin{abstract}
The radio as a vehicle of mass communication has undergone many changes over the years through the development of informatics and cybernetics. The process of digitization suffered by conventional broadcasters and the availability of its content on the Internet, produced the latest step in the recent history of media - the Web Radio. In turn, the education has been used in the new technological resources to produce educational programs multidisciplinary in several areas of knowledge and in different parts of the world. Therefore, the present educational-communicative paradigm requires a new way of thought about the pedagogic models and new intervention strategies in society, which are able to respond to contemporary educational and intervenient processes. In this sense, the radio has been a great ally for Education for over one hundred and fifty years, taking the information and knowledge to the most inhospitable places. Nowadays, with a web format, the radio makes available, in virtual space, an ample group of technological interfaces with an alternative and complementary environment of teaching-learning. Appears, therefore, learning through the Internet radio, providing the virtual space and a set of interfaces for technology that teachers can disseminate their scientific work, suggest readings, stimulate debate on issues related to discipline (forums discussion), information notes, reviews, interviews with local experts and invited, promotion of academic events (congresses, seminars, lectures, conferences or meetings), lessons in podcast, beyond the possibility of synchronous communication with the network, through email, blog, facebook, forum, messenger, chat, myspace, twitter and others. In this communication, we will make a reflection about the web radio, showing its present panorama as an educational-communicative media and highlighting the case study of the Rádio Universitária do Minho (RUM).
\end{abstract}

Key-Words: Radio Web, E-Learning, Collaboration, Multimedia Sharing, Interactivity.

\footnotetext{
${ }^{1}$ Text produced under the individual program Doctor Foundation for Science and Technology of Portugal (FCT), integrated in the Center for Research in Education (CIED) - University of Minho. Project: Information Society, Innovation and educational processes.
} 


\section{Introduction}

The virtual environments can be considered as one of the factors driving the transformation of mass media, associating new forms in network communication and making the information more accessible to any person that has access to the worldwide network of computers, promoting the production and dissemination of information in science and technology for teaching and research in all areas of knowledge and different sectors of society. According to Castells (2009), it is fundamental to think of communication as a necessary element of sociability, understanding the act of communicating from its symbolic nature and inherently cultural. Lévy (2010) adds to that, asserting that the Collective Intelligence is a determining factor in competitiveness, creativity and human development in a knowledge based economy, or in an information economy in the Network Society.

Communications technologies allow for the annihilation of distance and for globalization; the potential for rapid, synchronous and asynchronous communication also changes the relationship to time (Castells, 2000a). This is because communication technologies, such as the Internet, allow for decentralization of operations and focusing of control, increasing the effectiveness of networks relative to hierarchical structures (Castells, 2000b).

However, it was the ability to connect these technologies together, giving rise to such networks, which expanded and integrated the individual and groups into a wider setting and new standards of globalization. As regards education, it is considered that this new configuration allows communication to expand the territory of the local school to deterritorialized areas of knowledge, enabling viewing school as a true learning community (Silva, 2002).

Commenting on the link between information and learning, Pinto (2002, p.185) concludes that "information is present, more and more complex and frequent, in the environment surrounding the learner. His/her perceptions build in a structured manner (education) an informational model that he/she uses to survive in this very environment". When it comes to mass media that develop sociocultural activities of informal and non-formal education, they almost always include formal programs when oriented directly to the school's curriculum. That is the case of school and college webbroadcasted radio stations, which have an informative nature, but are very much biased towards formativeness, establishing mixed-type educommunicative configurations.

The educommunicative paradigm online requires a new way of thought about the pedagogic models and new intervention strategies in society, which are able to respond to contemporary education. The radio as a vehicle of mass communication has undergone many changes over the years through the development of informatics and cybernetics. The process of digitization suffered by conventional broadcasters and the availability of its content on the Internet produced the latest step in the recent history of media: The web radio. In turn, the education has been used in the new technological resources to produce educational programs that are multidisciplinary in several areas of 
knowledge and in different parts of the world, with a proposal of rupturing from the traditional educational model based on a linear transmission of knowledge.

Hence, the main activity yet to be developed by educators is to advise educational institutions on the use of new technologies as a didactic support, promoting and spreading their educational applications inside and outside classrooms. That is the case of web radio representing a valuable space for the popularization of information, education and the socialization of culture, and that can be accessed at anytime and anywhere in the world.

In this sense, we will make a reflection on the web radio presenting its present panorama as an educational-communicative media and highlighting the case study of the Rádio Universitária do Minho (RUM).

\section{Methodology Adopted in the Investigation}

Given the characteristics of the study, the research methodology used was of qualitative, descriptive and interpretative, using the technique of content analysis (analysis of programs online), and random samples by the application of a questionnaire survey with 203 students from different courses at the University of Minho on their perceptions about the web radio (the research was conducted on the Campus of University of Minho).

As techniques and instruments for data collection: Information survey on the web (analysis of university web radios in Portugal); document analysis (through the technique of content analysis - program grids); the observation of portuguese university radio programs, and the analysis of the formative tendency of Rádio Universitária do Minho (RUM). The data collection was processed in the second quarter of 2009, and the treatment of data's was made at this time by using at statistic program SPSS 17.0.

We also used the classification of radiophonic categories from Filho (2003), which could be categorized in: Journalistic (note, news, bulletin, reporting, interview, comment, editorial, chronicle, journalistic documentary, round-tables or debates, police program, sportive and techno-scientific programs); Educative-Cultural (autobiography, educative-cultural documentary, thematic program); Entertainment (musical program, fictional program and artistic event); Publicity (spot, jingle, testimonial, promotion piece); Advertising (public action radio-phonic piece, electoral and religious programs); Service (notes of public utility and service); Special (children's program, varieties program).

\section{Results}

\subsection{The concept of Web Radio}

The web radio can be defined as the radiophonic emission on the Internet in real time, usually in audio formats (MP3 or MP4, OGG Vorbis, WebPlayer, Real Audio, Windows Media Audio and HE-ACC). Different from traditional radio, your transmission could be followed by images, videos, texts, pictures and links. This 
advance allows the listener to do much more than just listen, making communication much more dynamic. Currently, it is possible to conduct online education, offering didactic material in PDF files or Word documents, video, podcast, and have access to up-to-date information through the feed RSS, clear up doubts with the instructor / educator through messenger, e-mail, chat, twitter, forums, as well as the interactivity in real time, through audio-conference or video-conference. It is about the combination of various elements: Ubiquity; flexibility; low cost; emission in real time; synchronous and asynchronous communication; multi-directed connectivity; multimedia sharing; streaming; collaboration and the interactivity integrated with e-learning.

Often, the online reproduction of hertz signal through codification in the personal computer, through streaming, reproduces the emission on the Internet. The data is sent from personal computer packages for audio, video, text, images for Internet, which are stored on the platform online and made available to the public, which has access to a range of interactive resources. To Lee (2005) and Geller (2007), the web radio is nothing more than digital radio with support of the Internet, which allows the presence of audio, video, text, and promoting the emergence of new genres and new forms of interaction.

Thus, the main differences between traditional radio and Internet radio are the ways of accessing radio: By the computer; the flexibility of synchronous and asynchronous programming; geographical coverage (from local to global); the quality of emissions (without interference or noise), and active participation of the public. The user not only listens, but reads, writes and assists the programs of radio, having at their disposal a set of integrated interfaces. Finally, the interactive multimedia together with the audio in virtual environment is the essence of what has been called "web radio", which has the potential advantage of network, enriching its programming with multimedia content and additional resources, allowing a constant interaction transmitter-receptor (Perona Páez \& Veloso, 2007).

In some countries, the web radio is being used as an educational interface in virtual learning environments responsible for the divulging of various cultural activities on schools or universities, with programs dedicated to music, theater, cinema, education, science, technology, politic, poetry, literature, economy, news and transmission of popular festivals.

\subsection{University Web Radios in Portugal}

The first university radio in the world appeared on $19^{\text {th }}$ November 1923 in Argentina it was called the Radio Universidad. Since then, university radios followed up the evolutionary course of the common radio over the decades, representing the interests of the academic community. Such as web educational and training radio projects that emerged in the late 90's, the online broadcasters, brought up in the university departments, and the university radios began to supply a range of services and applications that did not exist till then. Unlike conventional radio, Internet radio immediately sparked the interest of the broadcasting companies, once it did not impose limits on the listener's geographical range, nor on the exclusive audio format programming. 
It can be said that communication is an element which acts on individuals, as it is through it that people interact with each other, exchanging information. Therefore, understanding communication results in the perception of human relations, in a process involving individualities, stories, feelings, values and ways of perceiving the world, bringing on changes in the way society individuals feel, think and act.

In Portugal exists a reasonable number of academic broadcasters which are primarily characterized by a great range of varied programming, including numerous fields in which it is possible to find all kinds of genres and issues. In addition, university radios are broadcasters that foster radio-creation becoming themselves real alternatives to the general radio dominant content, as they offer a vast collection of "information, education, culture and entertainment". This radio stations are characterized by presenting a programmatic heterogeneous grid with respect to content, thus emerging as another option to the ordinary programming of the major conventional broadcasters. In fact, among the generalist portuguese radios, the Information and the Entertaining and Cultural Magazines hold 60\% of the total offers, while sport only represents little more than 5\%. The remaining percentage is reserved for Music and participation spaces and, to a lesser extent, for Education and other minority genres (35\%), with only a sporadic presence on university radio stations. This programmatic uniformity becomes even more apparent if we bear in mind that the different networks choose to transmit the same contents at the same time schedule, affecting a vast majority of broadcasters, including those that have been managed in recent years. Along with a worldwide trend and according to researches carried out within this area, online radios should not be restricted to "generalist" functions, but should also be a combining tool with a complementary interface aimed at people's education, whether it is instructive or informative.

According to Teixeira (2009), the Rádio Universitária de Coimbra (www.ruc.pt), from Universidade de Coimbra; the Rádio Universitária do Marão (www.universidade.fm), from the Trás-os-Montes and Alto Douro Region; the Rádio Universitária do Algarve (www.rua.pt), from the Universidade do Algarve; the Rádio Universitária Beira do Interior (www.rubi.ubi.pt), from the Universidade Beira do Interior; the Radio Zero (www.radiozero.pt), from the Instituto Superior Técnico and the Rádio Universitária do Minho (www.rum.pt), from the Universidade do Minho, are the Portuguese University Web Radios. In global terms, it is possible to assert that they share similar objectives, but have different and heterogeneous structures and program typologies (Cordeiro, 2005).

These radios have not delayed in employing the technological resources of web radio, fact that can be sustained by the quantitative growth of online platforms, through which people can have access to the ordinary programming in real time by means of a great variety of devices connected to the Internet. We will proceed with the presentation of the results in accordance with the objectives of this research, now analysing the web radios in the Portuguese academic universes. For that purpose, we made a selection of some experiments using Perona Páez and Veloso's selection criteria of "Radio Educational Modalities” (2007). 


\subsubsection{Structure of Operation}

The Rádio Universitária de Coimbra (RUC) exists since 1986 and was one of the first university radios in Portugal with web emission. Nowadays, it develops its activities based on the following categories: the formative, the informative, the academic and the cultural-educative. The formative category is established through periodic courses of formation and recycling for speakers, editors/speakers and technicians, besides the realization of didactic programs in collaboration with public and private institutions. The informative category is a space focused on the debate of questions related to the Universidade de Coimbra and to up-to-date news. About the academic life at the Universidade de Coimbra, the RUC dedicates an ample space in its program grid, transmitting the main occurrences of the learning institution. Finally, the cultural category is responsible for the divulging of various cultural activities going on in Coimbra, at the North Region or in the rest of the country, with programs dedicated to music, theater, cinema, poetry, literature and the transmission of concerts, shows and popular festivals.

The Rádio Universidade do Marão (FM Universidade) gave its first steps in the virtual world in 2000 (Cordeiro 2005), and since then the objective of the broadcasting station was to become the first university radio totally digital in Portugal. However, for technical reasons, this evolution to the web was only firmed in posterior years (Leão, 2007). Presently, the Rádio Universidade do Marão is focused on the academic public of the Trás-os-Montes and Alto Douro Region, with a purely informative focus.

In 2003, the Rádio Universitária do Algarve (RUA) arouse in a partnership between the Academic Association and the Universidade do Algarve. In the web, it has as an objective to divulge and promote the academic activities and cultural and musical events of the South Region in Portugal. Different from "RUC" and "RUA", it is grounded in three pillars to develop its activities: the Academy, the Culture and Alternative Music. The objective of the programs directed to the Academy is to show to the national Portuguese community the contributions that the Universidade do Algarve offers to the region and to the country, related to teaching and research. The Culture is centered on the promotion and divulging of cultural events that take place in the Algarve Region (popular festivals, concerts, shows, cinema, literature, theater). The Alternative Music programs promote the work of artists and bands unknown to the public in general and to the communication means.

Still in 2003 the Rádio Universitária Beira do Interior (RUBI) was created as a laboratory of the discipline radio-phonic Journalism at the Universidade Beira do Interior, only with an internal character. In 2004, the RUBI starts to emit its radiophonic program on the web, and started to be called "RUBIweb". But only in 2006 that the RUBI decided to bet on the diversity of categories in its program grid, aggregating multimedia interfaces to its web radio platform, such as the podcast and e-mail.

According to the Filho's (2003), radio-phonic classification of categories, Rádio Universitária Beira do Interior is exclusively generalist and informative, functioning as the "voice" of the Departments from the Universidade Beira do Interior, as well as of the local community, Covilhã. 
The Radio Zero is part of the Association of the Instituto Superior Técnico (IST), with its headquarters in Lisbon (before 2006 it was called RIIST - Internal Radio of IST). Being originally a radio of university character, its objectives are centered in offering radio-phonic formation to the students interested in working in radio, as well as inform the "IST" academic community about the main events going on at the university, in a cultural, scientific and educative ambit (http://www.radiozero.pt/projecto/). It has more than 40 programs on its online program grid of journalistic, cultural-educative and entertainment character (in its majority).

Taking advantage of the Internet interactive potentials, university radio stations seem to demonstrate a certain sensitivity in ensuring the rights of access and participation, something that has been increasingly neglected in other communicative fields.

\subsubsection{The RUM}

The Rádio Universitária do Minho (RUM) exists since 1989, and since 2006 it started to transmit via web, with a clearly heterogeneous program offer, on which spaces of purely formative-instructive character are mixed with others that explore different categories and formats, closer to some ongoing experiences in Europe. According to Leão (2007), the RUM launched two crucial interfaces in the context of its strategy to conquer and gain the loyalty of new public: the website and the online emission. The consolidation of the online emission, particularly, revealed as an alternative to the “conventional receptors”, emphasizing culture, debates on education, science, economy, politics, news, local informs, chronicles, interviews, and specialized reports.

In its relationship to the Universidade do Minho, the RUM makes available the virtual space and a group of technological interfaces for the lecturers to divulge their scientific works, suggest readings, stimulate the debate on themes related to their disciplines (discussion forums), to inform grades, tests, interviews, divulge local, national and international academic events (congresses, seminars, talks, colloquiums, meetings...), store lectures in podcast (in a way that the student can have access to the discipline contents in any part of the world), besides the possibilities of synchronous communication with the broadcasting station, through e-mail, blog, messenger, twitter, chat, facebook or myspace.

Besides, it is on the program grid that the RUM is most different from other Portuguese university radios, for its thematic diversity and of the programs dedicated to the educational-cultural and journalistic categories:

Caixa de Ferramentas (Tool Box) and the Diferença em $1^{\circ}$ Plano (Difference in $1^{\text {st }}$ Level) - debates and interviews and the promotion of specialized support services to attend the peculiarities of people with special needs;

Ciência para Todos (Science for All) and the Universidade Sem-Muros; (No boundaries University) at the Democracia Viva (Living Democracy) - promotion and divulging of the university's cultural and scientific activities; 
Campus Verbal (serves as a radio-phonic laboratory, where the students from the Institute of Literature and Science of the Universidade do Minho, of French and German areas, produce radio programs based on what they have learned in the lecture rooms, and store the contents at the university's website in a podcast format;

Olhar no Feminino (View on the Feminine) - discusses themes related to the female world;

Magazine da Educação (Education Magazine) and the Livros com RUM (Books with $R U M)$ - information and reflection on the Portuguese and international literary situation, with interview from critics, authors and specialists in literature;

Praça Município / Café com Blogs (Municipal Square / Coffee with Blogs) - debate about the Portuguese political scenario;

Eco RUM (Ecology RUM) - program focused on the protection and conservation of the environment;

Rumo Económico (Economic Route) - interviews and reports on the national and international economic panorama;

Cultura Impressa (Printed Culture) - the main topics of printed media are debated on the program;

Cultura Crónica (Chronics Culture) - program focused on stage arts, cinema, literature and shows;

Escola de Rádio (Radio School), where courses on the radio-phonic universe are developed (the courses are given by communication experts from the Rádio Universitária do Minho and lecturers of the Universidade do Minho), with more than 60 specialized programs divided by categories and for all public.

This is the Rádio Universitária do Minho, functioning as a social communication vehicle of local communities and as a valuable space for the divulgation, socialization and popularization of science and technology, produced by different departments at. According with the researcher Paula Cordeiro (2005), the contribution and influence of university radios in the development of the future professionals' formation, allied to the importance in the context of radio-phonic communication in general are incontestable, and, in a context where the main concern is the profit-making of the station, university radios appear as elements that offer alternatives of program and formation.

Based on a cooperative work, with interactivity among the participants and sharing of ideas, the interface "web radio" is presented as a mean through which the students feel an important and active part of the educational-communicative process. "This takes us to a proposal of rupture from the traditional educational model based on a linear transmission of discipline content, in which emission and reception are separate" (Fernandes \& Silva, 2004:379). 
Therefore, the alternative nature of the analysed broadcasting companies is marked by the exploitation of contents that can hardly be found in other grids, such as programs dealing with the problem of social exclusion, those which make science and knowledge popular, as well as those that emphasize less commercial music or that bring together cinema, literature and art. On the other hand, it presents a wide range of educational programs, ranging from formal and informal classes to professional and technical training courses and languages, thus providing an alternative and complementary teaching and learning background (Perona Páez \& Veloso, 2007).

For students, it represents an extension of knowledge and an interactive room outside the traditional classrooms, approaching Lévy's concept (1997) on "Cyberculture”, or even, on the virtualization process society faces nowadays, in which the virtual is not opposed to reality, but it complements it (Lévy, 2010). Classrooms today are no longer the only standard teaching, still less the exclusive learning area. Geographical boundaries are diluted; the world today is interconnected by the simultaneity of the new information and communication technologies. Thus, it is necessary to understand the contemporary changes at a social, political and economic level and the way they affect human relations in all society spheres.

Fig. 1. - Cultura RUM Website

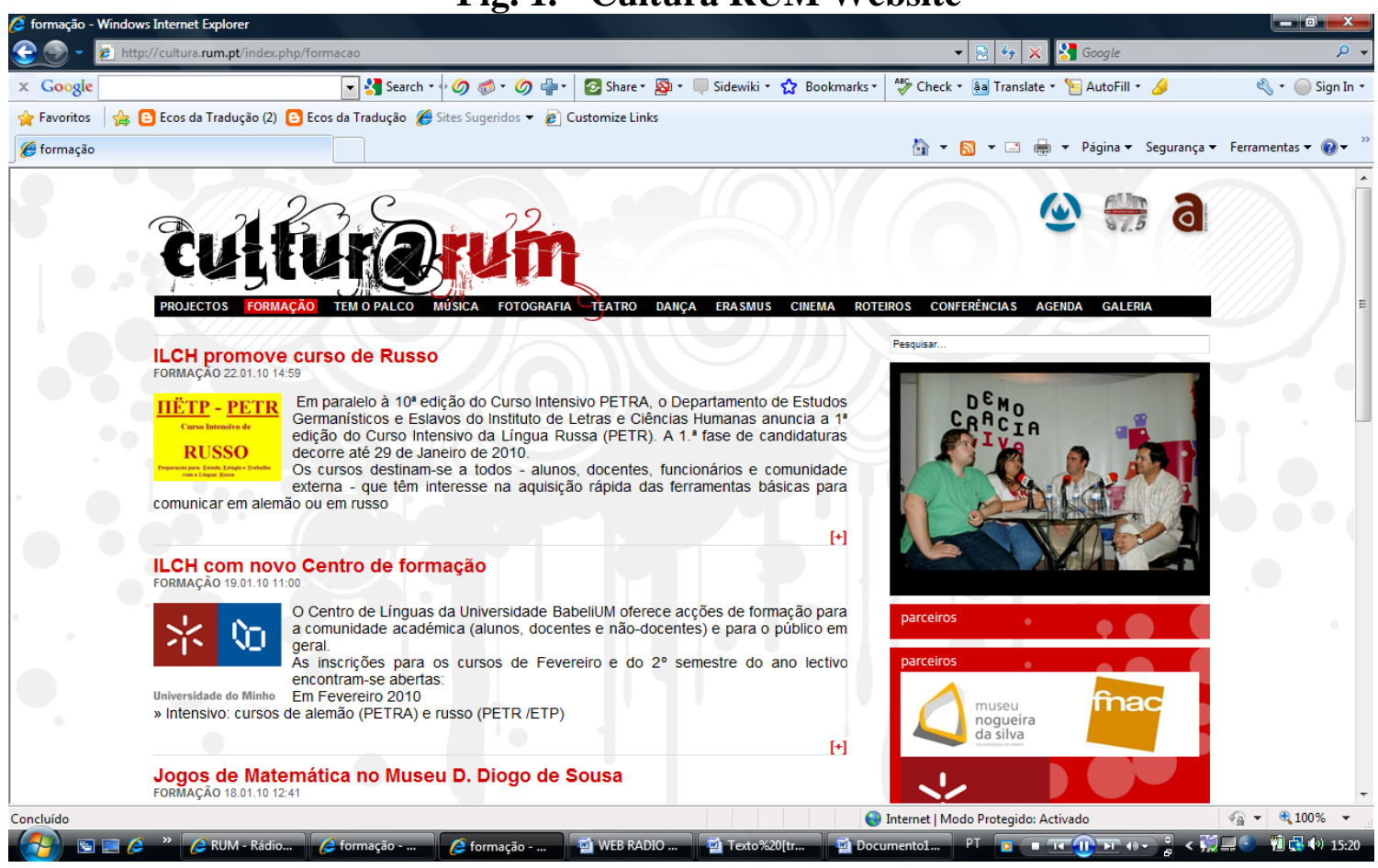

Font: (http://cultura.rum.pt/index.php/formacao).

As said by Díez (2009), the medias are instruments of public service, proving, at the same time, to be very useful in stimulating debate and in making easier for the students to understand the contents transmitted in the classroom. It is also reasonable to argue that teachers' new space and time perceptions, as well as those of the teaching and learning process as a whole, are of a crucial importance in establishing a school under new paradigms, achievable through the application of electronic age concepts, such as E-learning, Open School, University Without Walls (UWW) and Social Web, i.e. the 
socialization phenomenon already taking place at a global scale in an environment of sharing experiences, information and online learning (Correia \& Tomé, 2007). In the contemporary context, exploring web radio educational potentials seems to be a new challenge for educommunicators.

According Perona Páez (2009), the university radios are not restricted to generalist or informative functions anymore, but figure as a complementary or alternative mean for people’s formation.

\section{Conclusions}

The universities and schools through a web radio can provide educational programs in podcast with different themes for different courses or areas of knowledge, which will be available online and can be accessed at anytime and anywhere in the world. Through this technological resource, there is no possibility of losing the program if the person is busy, the programs are available online and can be accessed when necessary or possible. Such tendency is present in the objectives of the Rádio Universitária do Minho, through its social, cultural, educative and formative activities, both on conventional and web formats. However, the understanding of the web radio as an educational-communicative media has been followed by some difficulties related to the international academic community, in face of the still restricted investigation about the potentialities of online radio. Besides that, due to the similarity of its basic characteristics, it is common for the student public to confound podcast with web radio.

Another question to be considered is the need to create its own identity as a means of mass communication on the web, once it comes from a traditional media format. Even though it is still in need of a solid methodological-theoretical basis, the use of the web radio as a formative interface has been expanding significantly in the world.

In general, we believe that the radio web use as an educational interface has being significantly expanded throughout the world, though there is still a lack of a solid theoretical and methodological basis. In this sense, it becomes evident the need to more fully investigate the teaching and learning process through the web radio in educational institutions. In the Portuguese case, more specifically, it is crucial to deepen studies on the academic radio educational and training potentials and their contributions to the country. This is this study main suggestion for future research.

Despite the abovementioned obstacles, any course or discipline in school or at university, made available in a virtual learning environment, could use the radiophonic program, or produce, in a local radio station, contents to be shared by the students. It is only question of believing in the potential of the radio on the Internet and its potentialities.

\section{References}

Castells, M. (2009). Communication power. New York: Oxford University Press.

Castells, M. (2000a). Materials for an exploratory theory of the network society. British Journal of Sociology Vol. No. 51 Issue No. 1 (January/March 2000) pp. 5-24. 
Castells, M. (2000b). The Rise of the Network Society, Second Edition. U.S.: Blackwell Publishing.

Cordeiro, P. (2005). Experiências de rádio produzidas para e por jovens: o panorama português das rádios universitárias. Proceedings of the I Encuentro Iberoamericano de Radios Universitarias, 13-14 March 2005, Granada, pp.1-9.

Correia, C., Tomé, I. (2007). O que é e-learning. Lisboa: Plátano Editora.

Díez, D. (2009). Las rádios universitárias en España. Transformación al mundo digital. Telos - Cuadernos de Comunicación e Innovación, Julho-Setembro de 2009, nº80.

Fernandes, S., Silva, M. (2004). Criar e desenvolver uma rádio online na escola: Interatividade e cooperação no ambiente de aprendizagem, Revista da FAEEBA Educação e Contemporaneidade, XIII (22), pp. 375-384.

Filho, A. (2003). Gêneros radiofónicos - Os formatos e os programas em áudio. São Paulo: Paulinas.

Geller, V. (2007). Creating powerful radio: getting, keeping and growing audiences. Burlington: Focal Press.

Lee, E. (2005). How internet radio change the world. New York: iUniverse.

Lévy, P. (2010). From social computing to reflexive collective intelligence: The IEML research program. Information Sciences, 180, 71-94.

Lévy, P. (1997). Cyberculture. Paris: Odile Jacob.

Perona Páez, J. (2009). Edu-webs radiofónicas: experiencias españolas de educación en medios. Comunicar, 13, Vol.XVII, Revista Científica de Educomunicación, 107114.

Perona Páez, J., \& Veloso, M. (2007). Modalidades educativas de la radio en la era digital. Icono 14 - Revista de Comunicación Y Nuevas Tecnologías. Retrieved on April 2008 from http://www.icono14.net/revista/num9/articulos/08.pdf.

Silva, B. (2002). A Glocalização da Educação: Da escrita às comunidades de aprendizagem. In: O particular e o global no virar do milénio, Cruzar saberes em educação. Proceedings of the $\mathrm{V}$ Congresso da Sociedade Portuguesa de Ciências da Educação. Porto: Sociedade Portuguesa de Ciências da Educação, pp. 779-788.

Pinto, M. (2002). Práticas educativas numa sociedade global. Porto: Asa.

Teixeira, M. (2009). Análise da rádio web como uma interface dinamizadora da prática educativa: Estudo de Caso da RUM. Master Dissertation. Braga: University of Minho. 